\title{
A felületi érdesség CAD alapú modellezése nagytermelékenységü forgácsoló eljárásoknál
}

\author{
Felhő Csaba \\ egyetemi docens, Miskolci Egyetem, Gyártástudományi Intézet \\ 3515 Miskolc, Miskolc-Egyetemváros, e-mail: csaba.felho@uni-miskolc.hu
}

\begin{abstract}
Absztrakt
A cikkben ismertetésre kerülnek az EFOP-361-16-2016-00011 számú „Fiatalodó és megújuló Egyetem - Innovativ Tudásváros a Miskolci Egyetem intelligens szakosodást szolgáló intézményi fejlesztése" cimü projekt keretében a Gyártástudományi Intézetben elvégzett kutatásaink, amelyeknek a témája a felületi érdesség elméleti modellezése nagyteljesitményü forgácsoló eljárásoknál CAD modellezés segitségével. Ezen kutatásaink során elsösorban homlokmarással megmunkált felületek vizsgálatával foglalkoztunk, ahol az ún. forgácsarányt (az a fogásmélység és az $f_{z}$ élenkénti elötolás arányát) az általánosan alkalmazott $a_{p} / f_{z}>1$ tartományból az $a_{p} / f_{z}<1$ felé változtattuk. Jelen dolgozat keretében bemutatásra kerül a kidolgozott módszer lényege, valamint az elvégzett vizsgálatokat foglaljuk össze röviden.
\end{abstract}

Kulcsszavak: homlokmarás, felületi érdesség, érdesség modellezése

\begin{abstract}
The article describes our research carried out at the Institute of Manufacturing Science within the framework of the project EFOP-361-16-2016-00011 "Younger and Renewing University - Innovative Knowledge City - institutional development of the University of Miskolc aiming at intelligent specialization", with the topic of CAD-modeling of theoretical surface roughness in high-performance cutting processes. In the course of this research, we mainly dealt with the examination of surfaces machined by face milling, where the so-called the cutting ratio (ratio of the depth of cut $a_{p}$ and the feed per tooth $f_{z}$ ) was changed from the generally used range $a_{p} / f_{z}>1$ to $a_{p} / f_{z}<1$. In this work, the essence of the developed method is presented, and the performed investigations are briefly summarized.
\end{abstract}

Keywords: face milling, surface roughness, roughness modelling

\section{Bevezetés}

Napjainkban a forgácsoló eljárások fejlesztése során sokszor egymásnak ellentmondó célok elérésére törekednek a szakemberek: egyrészt a minél nagyobb anyagleválasztási sebesség elérésére (tehát a minél nagyobb termelékenységre), másrészt viszont az alkatrészfelületekkel szembeni fokozott igények kielégítésére. Mivel a termékminőség biztosítása már annak a tervezése során elkezdődik, így ennek jelentős szerepe van a gyártástechnológia tervezésénél is. A kutatásaink során mi a gyártmányminőség egyik fontos alappilére, a felületi érdesség vizsgálatával foglalkozunk nagy előtolással végzett homlokmarásnál. A felületminőség tervezésének (elöre jelzésének) egyik fontos módszere az adott geometriai és technológiai paraméterek mellett elérhető elméleti érdesség meghatározása, és a valós értékek becslése ezek alapján.

A kutatásaink során kidolgozásra került egy olyan új eljárás az elméleti érdesség meghatározására [1], amelynél a szerszám- és munkadarab geometriája, valamint az elméleti érdesség szempontjából 
leginkább meghatározó két technológiai paraméter: a fogankénti előtolás $\left(\mathrm{f}_{\mathrm{z}}\right)$ és a fogásmélység $\left(\mathrm{a}_{\mathrm{p}}\right)$ alapján elkészítésre kerül a megmunkált felület háromdimenziós CAD modellje. A modellezésnél két CAD rendszert is alkalmaztunk: a Siemens NX és az AutoDesk Inventor parametrikus CAD szoftvereket. A kidolgozott módszer lényege, hogy a modellezéssel kapott elméleti felületet egy célszerüen kidolgozott illesztőprogram segítségével lekérdezzük a CAD rendszertől (mivel szükség van a pontok x, y, z koordinátáira, amelyeket a parametrikus rendszerben alapból nem állnak rendelkezésre), majd ezeket elmentjük egy megfelelő fájlformátumba (mi a kutatásaink során a SURF fájlformátumot alkalmaztuk, amely a DigitalSurf cég által kifejlesztett és alkalmazott formátum a felületi pontok tárolására). Ezen fájlt pedig a Gyártástudományi Intézetben található AltiSurf 520 típusú érdességmérő gép kiértékelő szoftverébe (AltiMap) beolvasva elvégezhető a szabványos 2D és 3D érdességi paraméterek szerinti kiértékelés.

A modellezés mellett természetesen szükséges az adott forgácsolási paraméterekkel végzett valós forgácsolási kísérletek elvégzése, valamint az így kapott felületeken a fizikai érdességmérés elvégzése is, így megkapjuk a mért (valós) érdességi adatokat. Ezután ezeket két célra is felhasználhatjuk: egyrészt a modellezés során kapott értékek validálására, másrészt pedig az előzetes becsléshez szükséges összefüggések meghatározására. Ezen módszer nagy előnye, hogy így az elméleti és a mért értékek azonos bázison (azonos szoftver segítségével) kerülnek meghatározásra, amely az összehasonlítás során nagy elönyt jelenthet. Az általunk kidolgozott módszer elméleti folyamatábráját az 1. ábra mutatja.
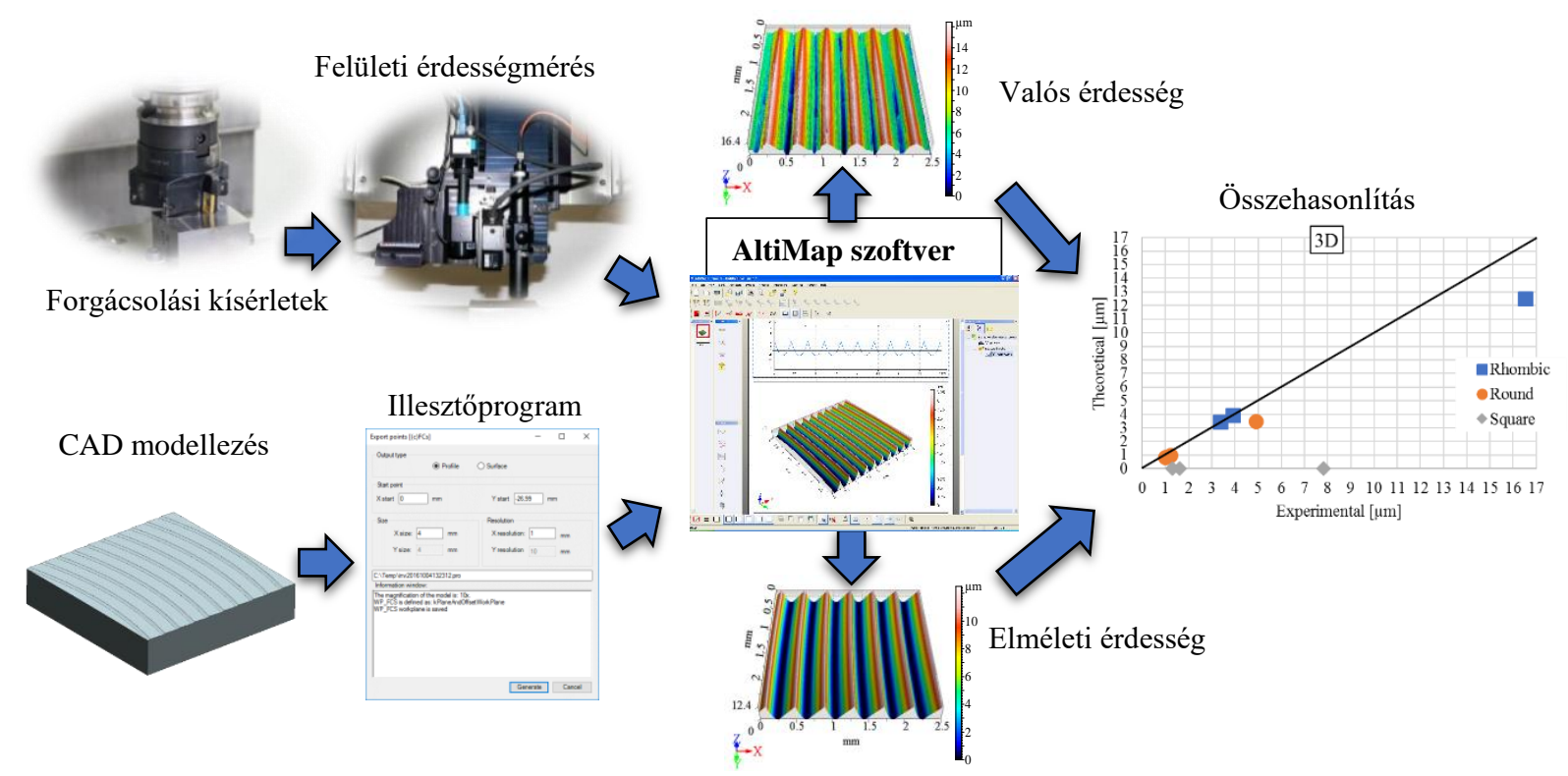

1. ábra A kidolgozott módszer folyamatábrája [2]

Fontosnak tartjuk továbbá megemlíteni a módszernek azt a rugalmasságát, hogy mivel az elméleti felület pontjai egy pontfelhő formájában a rendelkezésünkre állnak, ezért a későbbiekben lehetővé válik a marás dinamikus hatásainak (rezgések) a figyelembevétele az elméleti értékek számításánál.

A modellezésnél a szerszám- és munkadarab geometria tekintetében az alábbi főbb paramétereket vettük figyelembe:

- effektív szerszámátmérő $\left(D_{s}\right)$; 
- a forgácsoló lapka alakja és méretei (itt a lapka síkbeli leképezéséről van szó, mivel a lapka vastagságának és az ezen mérethez illesztett koordináta-tengely mentén értelmezett további jellemzőknek nincs közvetlen hatásuk az elméleti érdesség értékére);

- a munkadarab szélessége $\left(b_{\mathrm{w}}\right)$.

Az ismertetett paramétereken túlmenően a többélű forgácsoló szerszámok alkalmazásánál fellépő radiális és axiális beállítási hibákat is figyelembe vettük a modell készítése során [3]. Ez különösen nagy jelentőséggel bír az ún. „,inverz” forgácsoló eljárásoknál (ahol az $\mathrm{a}_{\mathrm{p}} / \mathrm{f}_{\mathrm{z}}$ arány egynél kisebb), hiszen az axiális eltérések az effektív fogásmélység értékét, míg a radiális ütés az effektív előtolást módosítják, ezáltal az élek terheléseloszlása is megváltozik. Ezen hatás vizsgálatához előzetes végeselemes vizsgálatokat is végeztünk [4].

Továbbá azt is vizsgáltuk a kutatásaink során, hogy a homlokmarásnál képződő jellegzetes felületi struktúra miatt a felületi érdesség hogyan változik a munkadarab szélein (onnan adott távolságban mérve) a szerszám belépő és kilépő oldalán [5].

\section{Az elvégzett vizsgálatok rövid bemutatása}

A következőkben röviden összefoglaljuk az elvégzett vizsgálatokat. Az [1]-ben a korábban már bemutatott módszer került ismertetésre, valamint konkrét elméleti felületek lettek prezentálva körlapkával (iC $=12 \mathrm{~mm}$ ) végzett ütőkéses megmunkálásnál. A modellezett és a forgácsolási kísérletek során mért két és háromdimenziós érdességi értékek ( $\mathrm{Ra}, \mathrm{Rz}, \mathrm{Sa}, \mathrm{Sz}$ ) alapján megállapításra került, hogy a módszer alkalmazásával jól közelíthető a valós érdesség. Ezen vizsgálat során egy Sandvik Coromant R200068Q27-12L típusú marófejet alkalmazunk RCKT1204M0-PM 4230 forgácsoló lapkákkal, a kísérleteket pedig egy Perfect Jet MCV-M8 CNC függőleges marógépen végeztük el. Az érdességmérésekhez az AltiMet cég AltiSurf 520 típusú érdességmérö berendezését alkalmaztuk, CL2 konfokális kromatikus távolságmérő szenzorral. A kísérletekhez C45 anyagminőségủ acél próbatesteket alkalmaztunk. Az alkalmazott fogankénti elötolás értékek: $\mathrm{fz}=0,5 ; 0,7 ; 0,9 ; 1,1 ; 1,3 ; 1,5 \mathrm{~mm}$ voltak, a fogásmélység értéke $0,9 \mathrm{~mm}$ volt, a fordulatszám $9501 /$ perc, a radiális fogásmélység $\mathrm{a}_{\mathrm{e}}=50 \mathrm{~mm}$ volt.

A 2. ábra a cikkben vizsgált felületek közül mutatja be a legkisebb és a legnagyobb előtolás mellett kapott elméleti és valós felületek háromdimenziós ábráit. Látható, hogy az elötolás növelésével egyre inkább közelítjük az elméleti topográfiát, hiszen a forgácsolás egyéb jellemzőinek a hatásai arányukban nézve egyre kisebbek.

Az adatok kiértékelése után összehasonlítottuk az elméleti és a valós érdességi értékeket, és megállapítottuk a korreláció mértékét. Ennek a szemléltetésére mutatjuk be a 3. ábrát, ahol a szemléltetés kedvéért berajzoltuk a tökéletes illeszkedést mutató $45^{\circ}$-os egyenest is. A vizsgálataink alapján megállapítottuk, hogy a modell és számítási módszer alkalmas a valós felületeket megfelelő közelítéssel leképezni, ezáltal az adott paraméterek mellett forgácsolt felületek várható érdességét elöre jelezni.

A [2]-ben további két lapkát vizsgáltunk a körlapka mellett, hasonló módszer alkalmazásával: egy R215.44-15T308M-WL típusú rombusz alakú valamint egy SEKN 1203 AFTN JC5030 típusú négyszög alakú forgácsoló lapkát. Az alkalmazott technológiai paraméterek a következők voltak: $a_{p}=0,8 \mathrm{~mm}$; $\mathrm{f}_{\mathrm{z}}=0,4 \mathrm{~mm} ; \mathrm{v}_{\mathrm{c}}=200 \mathrm{~m} /$ perc, $\mathrm{a}_{\mathrm{e}}=58 \mathrm{~mm}$. A forgácsolási kísérleteket itt is $\mathrm{C} 45$ anyagminőségen végeztük el.

A cikkben arra a következtetésre jutottunk, hogy a legkedvezöbb érdességet a körlapka alkalmazásával érhetjük el a három vizsgált szerszám tekintetében, ezt a négyszög majd végül a rombusz lapka követte. Azt is megállapítottuk, hogy a négyszög lapka tekintetében az elméleti érdességi értékek nullára adódtak, ennek oka, hogy a szabványnak megfelelően ez a lapka egy 1,5 mm-es „wiper” (megmunkált 
felülettel párhuzamos) élszakasszal rendelkezik, amelynek a feladata a felület „elsimítása”, tehát elméletileg nulla érdesség készítése. A valós felületeken természetesen megjelenik a forgácsoló lapka lenyomata, hiszen a gyakorlatban nem lehet nulla érdességü felületet készíteni, a beállítási hibák, a dinamikus hatások, az élérdesség, stb, miatt mindig lesz valamilyen mértékü egyenetlenség a felületen.

Elméleti felület
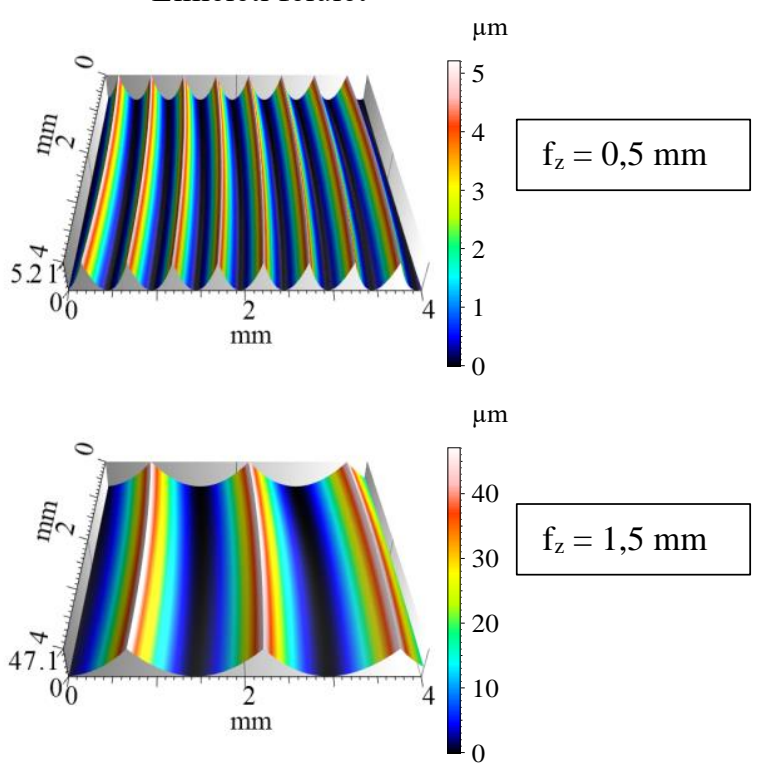

Mért felület
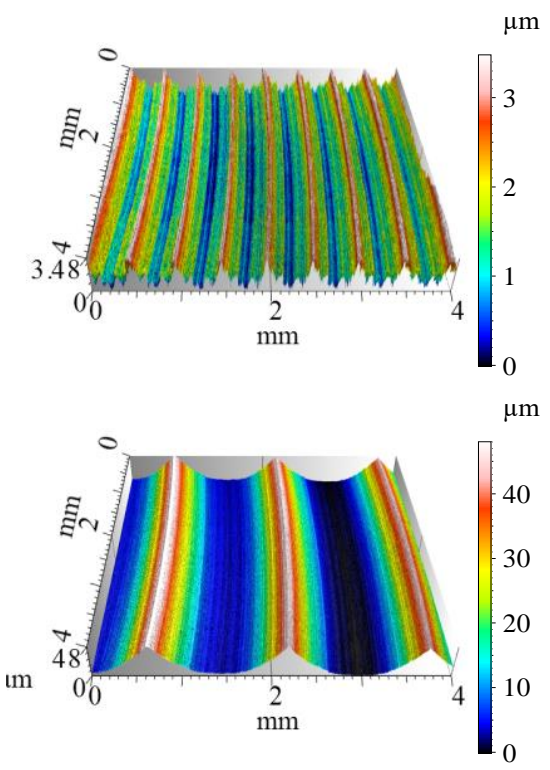

2. ábra Az [1]-ben bemutatott elméleti és valós felületek

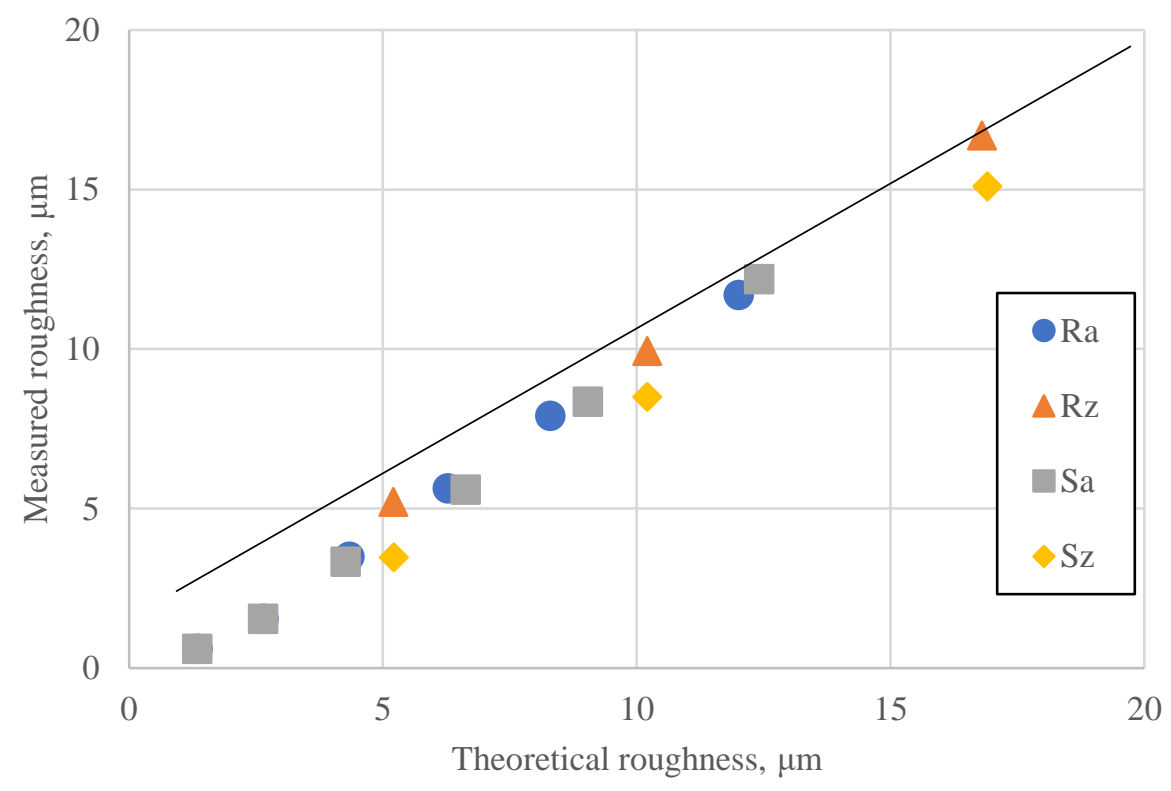

3. ábra Korreláció megállapitása az elméleti és a mért értékek között [1] 
A [3]-ban célzottan a lapkabeállítási hibák hatását vizsgáltuk a megmunkált felületek érdességére. Két kísérletsorozatot hasonlítottunk össze: elsőként az [1]-nél már ismertetett egylapkás kísérleteket az ott megadott geometriai és technológiai paraméterekkel, valamint ugyanazon szerszám alkalmazásával négy lapkát helyeztünk a marófejbe, az alkalmazott fogankénti előtolás értékek pedig a következők voltak: fz $=0,1 ; 0,3 ; 0,5 ; 0,7 ; 0,9 \mathrm{~mm}$. A többi paraméter megegyezett az egylapkás kísérleteknél ismertetettekkel. Itt szükség volt a beállítási hibák mérésére is, amelyhez a Zoller Hyperion típusú szerszámbemérő készüléket alkalmaztuk. A mérés során azt tapasztaltuk, hogy a körlapka geometriájából adódóan a radiális hibák nem játszottak szerepet a felület kialakításában, az axiális hibák igen. Ezeknek az értékeit 4-14 $\mu \mathrm{m}$ között mértük. A mért értékeket ezután figyelembe vettük a CAD modellezéssel készített elméleti megmunkált felület generálása során is, így azonos előtolás esetén a valós felületekkel jó egyezést mutató értékeket kaptunk. Erre példaként mutatjuk be a 4. ábrán látható érdességi profilokat.

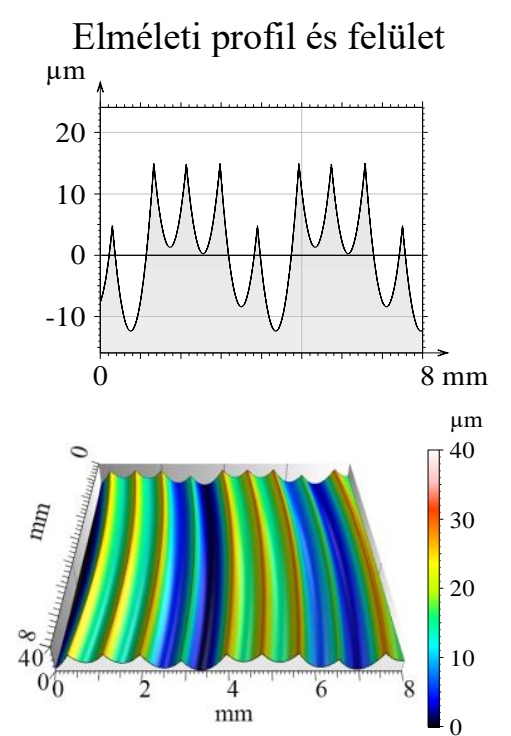

Paraméterek:
$4 \mathrm{db}$ körlapka
$\mathrm{iC}=12 \mathrm{~mm}$
$\mathrm{f}_{\mathrm{z}}=0,9 \mathrm{~mm}$
$\mathrm{D}_{\mathrm{c}}=68 \mathrm{~mm}$
axiális hibák figyelembe
vételével

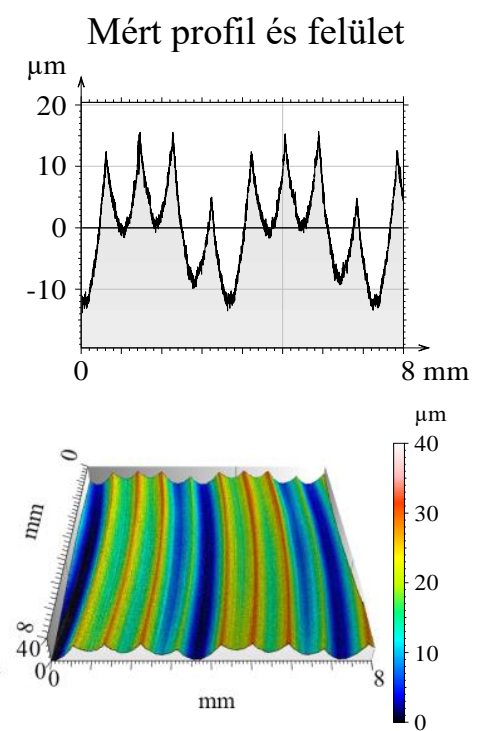

4. ábra A lapkák axiális beállitási hibáinak a figyelembe vétele az érdesség modellezésénél [3]

A [4]-ben ismertetett munka során azt vizsgáltuk, hogy nagyelőtolású homlokmarásnál alkalmazott megváltozott $\mathrm{a}_{\mathrm{p}} / \mathrm{f}_{\mathrm{z}}$ arány milyen hatással van a forgácsolás egyes állapotjellemzőire, úgy mint a forgácsoló erő bizonyos komponenseire ( $\mathrm{Fx}, \mathrm{Fy}, \mathrm{Fz}$ és Fc, Ff, Fp erőkomponensek), a forgácsoló nyomatékra, a teljesítményre és a forgácstőben ébredő maximális hőmérséklet értékeire. A vizsgálatokat a ThirdWave AdvantEdge végeselemes szoftverben végeztük el. Két forgácsoló szerszámot alkalmaztunk a modellezésnél: egy Garant XOEW 120508 PDER-W és egy Sandvik Coromant R24512 T3 EW K15W típusú forgácsoló lapkát. $\mathrm{Az} \mathrm{a}_{\mathrm{p}} / \mathrm{f}_{\mathrm{z}}$ arány értékét a $0,1 \div 10$ tartományban változtattuk. Ezen túlmenően változtattuk az axiális $\left(\gamma_{\mathrm{p}}\right)$ és a radiális $\left(\gamma_{\mathrm{f}}\right)$ homlokszög értékeit is a következő tartományban: $\gamma_{\mathrm{p}}=-40^{\circ}$ $\div 0^{\circ} ; \gamma_{\mathrm{f}}=0^{\circ} \div 12^{\circ}$. Az elvégzendő elemzéseket teljes faktoriális kísérlettervezés módszerével terveztük meg. Arra jutottunk, hogy a megváltozott $\mathrm{a}_{\mathrm{p}} / \mathrm{f}_{\mathrm{z}}$ arány hatására megváltozik a forgácsleválasztás jellege, a fö- és mellékforgácsoló élek felcserélődnek és a forgácsoló erők minimalizálása céljából célszerủ a minél nagyobb axiális és minél kisebb radiális homlokszögek alkalmazása. Ezen túlmenően $\mathrm{az} \mathrm{a}_{\mathrm{p}} / \mathrm{f}_{\mathrm{z}}$ arány csökkentésével (az elötolás növelésével) Fc, Ff erőkomponensek, így a nyomaték és a teljesítmény, valamint ezzel kapcsolatban a forgácsolási hömérséklet is csökkenthető. 
Az [5] cikkben közölt vizsgálatok során azt elemeztük, hogy a munkadarab megmunkált felületén a marófej középvonalától adott távolságokban hogyan változnak a felületi érdességi jellemzők a középvonalban mért adatokhoz képest. A vizsgálatokat a [3]-ban ismertetett forgácsolási körülmények mellett végeztük el (ütőkéses megmunkálásnál). Azt tapasztaltuk, hogy a szélek felé haladva az érdesség csökkenő tendenciát mutat, amelyet az elméleti modellezés eredményei is igazoltak. A valós felületek mérése során jelentős eltéréseket tapasztaltunk továbbá a belépési és a kilépési oldalon mért adatok között a középvonaltól azonos távolságban, amelynek oka a forgácsképződés során fellépő deformáció, sorjaképződés és a dinamikus hatások lehetnek.

A [6] munka során szintén a [3]-ban már bemutatott elemzésekhez hasonlóan a lapkák beállítási hibáit modelleztük, azonban itt egy Canela 0748.90.063 típusú marófejet vizsgáltuk, Dijet SEKN 1203 AFTN JS5030 típusú forgácsoló lapkákkal, konstans elméleti forgácskeresztmetszettel $\left(\mathrm{A}_{\mathrm{c}}=0,08 \mathrm{~mm}^{2}\right)$, változtatott $\mathrm{a}_{\mathrm{p}}(0,2 \div 0,8)$ és $\mathrm{f}_{\mathrm{z}}(0,1 \div 0,4)$ mellett. Ennél a kísérletnél 5 lapkát alkalmaztunk, amelyeknek mértük az egymáshoz viszonyított axiális ütéseit, és ez alapján generáltuk le a háromdimenziós elméleti felületeket, valamint értékeltük ki az érdességi értékeket. Itt szintén jó egyezést tapasztaltunk a valós adatokkal.

\section{3. Összefoglalás}

A kutatás során elvégzett elméleti és kísérleti vizsgálatok alapján megállapítható, hogy a kidolgozott módszer alkalmas az adott feltételek mellett forgácsolt felületek elméleti érdességének a meghatározására homlokmarásnál. Az ismertetett munkákban részletesen bemutattuk a módszer lényegét, a modellkészítés folyamatát, a kidolgozott illesztőszoftver felépítését és müködését. Valós szerszámok modellezésével több elméleti profilt illetve háromdimenziós felületet is generáltunk, ahol figyelembe vettük a többélű forgácsolószerszámok esetén fellépő beállítási hibákat is. Ezután meghatároztuk az elméleti érdességi paramétereket az AltiMap szoftverben. Az elméleti vizsgálatokat minden esetben valós forgácsolási kísérletek során végzett mérések adataival validáltuk, illetve meghatároztuk a várható érdesség elöre jelzéséhez szükséges összefüggéseket is. Az elvégzett kutatómunka eredményeit hazai és nemzetközi folyóiratokban illetve konferenciákon mutattuk be.

\section{Köszönetnyilvánítás}

A cikkben ismertetett kutató munka az EFOP-3.6.1-16-2016-00011 jelü „Fiatalodó és Megújuló Egyetem - Innovatív Tudásváros - a Miskolci Egyetem intelligens szakosodást szolgáló intézményi fejlesztése" projekt részeként - a Széchenyi 2020 keretében - az Európai Unió támogatásával, az Európai Szociális Alap társfinanszírozásával valósul meg.

\section{Irodalom}

[1] Kundrák, J., Felhő, C. A Method for the Determination of Theoretical Roughness in Face Milling Considering the Run-Out of the Inserts. Solid State Phenomena 2017, 261(1): 251-258. https://doi.org/10.4028/www.scientific.net/SSP.261.251

[2] Felhő, Cs., Nagy, A., Kundrák, J. Effect of Shape of Cutting Edge on Face Milled Surface Topography. Lecture Notes In Mechanical Engineering 2020: 525-534. https://doi.org/10.1007/978-3-030-31343-2_46

[3] Felho C., Kundrak, J. Effects of Setting Errors (Insert Run-Outs) on Surface Roughness in Face Milling When Using Circular Inserts. Machines 2018, 6(2): 14. https://doi.org/10.3390/machines6020014 
[4] Karpuschewski, B., Kundrák, J., Felhő, C., Varga, G., Sztankovics, I., Makkai, T., Borysenko, D. Preliminary investigations for the effect of cutting tool edge geometry in high-feed face milling. Lecture Notes In Mechanical Engineering 2018: 241-254. https://doi.org/10.1007/978-3-319-75677-6_20

[5] Kundrak, J., Felho, Cs. Investigation of the Topography of Face Milled Surfaces. Materials Science Forum 2018, 1: 78-83. https://doi.org/10.4028/www.scientific.net/MSF.919.78

[6] Kundrak, J., Felho, C. Topography of the machined surface in high performance face milling. Procedia CIRP 2018: 340-343. https://doi.org/10.1016/j.procir.2018.09.030 